\title{
Trends in the Presentation of Cell Biology and Histology in Contemporary Histology Books as Revealed in Their 'Preface's
}

\author{
Nahid Farhana Amin ${ }^{1}$, Khondker Manzare Shamim ${ }^{2}$ \\ ${ }^{1}$ Assistant Professor, Anatomy, Anwer Khan Modern Medical College, Dhaka, ${ }^{2}$ Professor \& Chairman of the Department of Anatomy, \\ Bangabandhu Sheikh Mujib Medical University (BSMMU), Bangladesh
}

\begin{abstract}
Baground: Teaching and learning of Cell Biology and Histology have gone through remarkable changes in recent times. The undergraduate medical courses in Bangladesh have incorporated some of these changes but seem to have some more way to go. Good Histology books are supposed to be reflectors of the desirable changes and of the present trends in teaching-learning and assessment in the subject in good institutions. Analyses of the 'Preface's of these books can help in developing an insight into the approaches taken and means applied in presenting Cell Biology and Histology in the books for meeting the demands of time. This insight, in turn, would guide the curriculum planners of the country and others seeking for changes in taking necessary steps. Objectives: To analyse the 'Preface's of contemporary Histology books, qualitatively, for noting the approaches taken and means applied in presenting Cell Biology and Histology in the books. Methods: The study was descriptive, observational and qualitative in nature, carried out in the Department of Anatomy, Bangabandhu Sheikh Mujib Medical University (BSMMU), Dhaka, between July 2007 and June 2008. The study materials were the 'Preface's of fifteen Histology books dealing with Cell Biology and Histology, published since 1984. The 'Preface's were analysed qualitatively to identify the information provided and comments made by their authors/editors on the approaches taken and means applied in the books in selecting and presenting topics, text and illustrations. The observations were organised into specific 'theme's. Results: Sixteen 'theme's could be identified. These include, among others, special emphasis in the books on following curricular reforms, incorporation of new information and special focus on the relationship of structures with functions. Additions and improvements regarding tables and illustrations are also highlighted. Conclusion: By incorporating the findings of the present study with the present-day ideas and trends in Cell Biology and Histology teaching-learning and assessment in the renowned institutions of the world, as evident from the available literature, suggestions can be formulated on improving the methods of teaching and assessment in Cell Biology and Histology in Bangladesh.
\end{abstract}

Key words: Preface, Histology books, Cell Biology and Histology, trends.

[BSMMU J 2012; 5(1):46-54]

\section{Introduction:}

The concept of learning is changing in the present day world. People are inclining towards practically oriented learning. Medical education is also in this streamline, and education in Anatomy is no exception. Cell Biology and Histology are integral parts of the medical undergraduate Anatomy curriculum of Bangladesh and of many other countries of the world. A total of 96 hours has been allotted to these subjects in the existing undergraduate medical curriculum of Bangladesh, ${ }^{1}$ and the assessment system has kept separate slots for them.

Address for Correspondence: Dr. Nahid Farhana Amin, Assistant Professor, Anatomy, Anwer Khan Modern Medical College, Dhaka
A broad overview of where these subjects lie in the broader context of medical science and how they are seen from a perspective of modern medical education would reveal some "points to ponder". Those are:

i) Body functions and dysfunctions are tried to be understood by developing understanding of body structures at microscopic, molecular and developmental levels.

ii) Addressing the understanding and critical thinking levels rather than mere factual levels of cognitive domain is advocated in the context of learning.

iii) Efforts are made to guarantee that students gain learning experience about things and events as they occur in real life situations. 
iv) The visual nature of the two subjects is highlighted and the need for ensuring visual experience using varieties of tools in learning the subjects is emphasized.

v) Different newer methods of studying cells and tissues are emerging to open up new horizons of understanding.

vi) New information and concepts are being added exponentially to the fields of Cell Biology and Histology, and this vast amount of information has to be accommodated into our knowledge by selection on the basis of importance.

vii) Time allocated for Anatomy, and thereby for Cell Biology and Histology, has been reduced in many universities.

However, although no systematic study has been done to provide useful evidence, it is felt that the undergraduate courses of Bangladesh are not being able to meet the demands of time in every aspect of Cell Biology and Histology. Teachers often complain that the students seldom develop proper understanding of the subjects and resort instead to rote memory and non-visual theoretical information-gathering. As "Histology sets the stage for subsequent studies of abnormal structure and function" ${ }^{2}$, the situation raises serious concerns. There are also variations among the teachers regarding the weights given to different topics of the subjects and about the ways the topics are dealt with in teaching and assessment. Moreover, teachers vary on how they should use various sorts of teaching-learning tools during instruction and assessment.

In recent years, some positive developments have been made in the organisation of teaching-learning and assessment of Cell Biology and Histology in Bangladesh. Apart from a new curriculum, some guidelines have been formulated for assessment that have been published as the "Module on the $1^{\text {st }}$ Professional MBBS Examination system to be held in January 2008 Based on New Curriculum"3. A formal OSPE has been introduced substituting the "spotting exam" (that had no procedure station) and some amount of structuring of the oral and practical examinations have been implemented.

But the nature and diffusion of the philosophical understanding that should govern these changes is not easy to measure. Moreover, translating this understanding into practical measures for providing appropriate learning experiences to students or in assessing their competencies may be difficult to achieve in many situations and for many teachers. Being exposed to the experiences of the teachers of renowned institutions of the world that are setting the new trends in teaching and assessment in Cell Biology and Histology is a good way of solving this problem. However, it is not easy to have such an exposure first hand.

Journal articles on the newer trends can provide secondary ways of getting close to such experiences. Another way of getting insight into the issue is analysis of Histology textbooks, especially those recommended by the renowned institutions of the world. This is because these textbooks should reflect not only the philosophy followed and learning objectives set by these institutions for the subjects but also the topics to be learned and the methods to be used for ensuring that learning.

Thus, it may be assumed that analyses of the 'approaches taken' and 'means applied' in presenting Cell Biology and Histology in contemporary Histology textbooks should indirectly be able to provide an understanding of the modern-day teaching-learning and assessment trends in the subjects. This understanding, in turn, can guide the curriculum planners in bringing about necessary modifications in the curriculum. It is again understandable that the 'Preface' of a book is the gateway to the understanding of the nature of the book. It usually tries to explain in brief why the book has been written and targeting whom, what philosophical standpoint has been chosen to approach the subject, how the text and illustrations have been organised to materialise the philosophical objectives and what are new in a particular edition to meet the demands of time.

Therefore, the present study was designed to examine the available 'Preface's of the contemporary Histology books:

- To analyse the approaches taken in presenting Cell Biology and Histology

- To analyse the means applied in presenting Cell Biology and Histology

\section{Methods:}

The study was descriptive, observational and qualitative in nature, carried out in the Department of Anatomy, Bangabandhu Sheikh Mujib Medical University (BSMMU), Dhaka, between July 2007 and June 2008. The study materials were the 'Preface's of the latest editions of the Histology books dealing with Cell Biology and Histology relevant to medical undergraduate courses and available in the medical libraries of Dhaka or through online sources. Fifteen such books ${ }^{2,4-17}$ were available for analysis after excluding the following: 
- Books titled purely as atlases

- Books on Cell Biology only (not including Histology)

- $\quad$ Books published before 1984

The following operational definitions were set for the study:

'Preface': "A preface is defined as an introduction to a book" 18 . In the present study, the introductory notes of each selected book designated as 'Preface' were considered as a 'Preface'.

'Cluster': A collection of similar information or comments that could be identified in one or more 'Preface's was termed a 'cluster'. From each cluster, one 'theme' could be deducted (Figure 1).

'Theme': A statement phrased by the present researcher that expressed the essence of the information and/or comments presented in a 'cluster'.

'Approaches taken' (in presenting Cell biology and Histology): This term meant

"All of the chapters have been revised and updated to incorporate current information........still retain the emphasis on the relationship between cell structures and function through the vehicle of cell and molecular biology. A tremendous amount of material has been compressed into a concise but highly comprehensive presentation."

\begin{tabular}{|c|c|}
\hline $\mathbf{A}_{1}$ & $\downarrow$ \\
\hline Cluster: 1 & $\begin{array}{l}\text { "All of the chapters have been revised and } \\
\text { updated to incorporate current information" }\end{array}$ \\
\hline Cluster: 2 & $\begin{array}{l}\text { ".......still retain the emphasis on the } \\
\text { relationship between cell structures and } \\
\text { function through the vehicle of cell and } \\
\text { molecular biology." }\end{array}$ \\
\hline Cluster: 3 & $\begin{array}{l}\text { "A tremendous amount of material has been } \\
\text { compressed into a concise but highly } \\
\text { comprehensive presentation." }\end{array}$ \\
\hline
\end{tabular}

what, according to the author(s)/editor(s), determined the way the book has been written and organised. Thus, the approaches for which evidences were looked for in the 'Preface's in the present study included the philosophy that determined which way the book would deal with the presentation of its contents. This was guided usually by the demands of the curricular form to be addressed (e.g., system-based Anatomy or region-based Anatomy) and the characteristics of the courses to be catered (e.g., shorter or longer) by the book. Also considered as the approaches were the strategies followed in the book to fulfill the demands of the underlying philosophy (e.g., the amount of clinically-oriented and/or problem-based material and the relative proportions of material addressing the understanding and critical thinking levels and the recall level of cognitive domain).

'Means applied' (in presenting Cell Biology and Histology): This term meant what specific ways, according to the author(s)/editor(s), have been used in the book to meet the demands of the underlying philosophy following the strategy selected. For example, use of clinical

"This textbook therefore presents a comprehensive survey of many of the complex interrelationships that exist between the structure and function of cells and tissues. ....Its text corporates a substantial amount of recent information, and to facilitate learning, its contents have been appropriately compacted and restructured. ....the total length of this edition has been decreased by $25 \%$."

\section{$\mathbf{A}_{2}$ \\ Cluster: 2 This textbook therefore presents a comprehensive survey of many of the complex interrelationships that exist between the structure and function of cells and tissues.}

Cluster: 1 "....Its text incorporates a substantial amount of recent information,"

Cluster: 3 "and to facilitate learning, its contents have been appropriately compacted and restructured. ....the total length of this edition has been

$\mathbf{B}_{2}$

C Theme 1: Attempts have been made to incorporate contemporary and new information.

Theme 2: Attention has been focused on better understanding of function based on the structures of cells and tissues.

Theme 3: There is a trend of compressing the volume of the book.

Fig. 1 Procedure of the analyses of 'Preface's. A1: A portion of the 'Preface' of Gartner et al. (2007). A2: A portion of the 'Preface' of Cormak (1987). B1 \& B2: Identification of similar information, explanations and comments in the two 'Preface's to form three 'cluster's for each. C: The 'theme's, one of which emerged from each 'cluster'. (In practice, the clusters were identified by highlighting them on the photocopies of the 'Preface' with highlighters of different colours). 
descriptions or discussions, problems, problem-based questions and answers and/or illustrations to make the contents more clinically oriented. Relative proportions of photomicrographs, electron micrographs, schematic diagrams etc. in presenting information on various histological structures were also considered as 'means applied'.

\section{Methods of analysis of 'Preface's to determine the 'theme's:}

The 'Preface' of each of the selected Histology books was read repeatedly and thoroughly. Important notes were taken on the principal information provided, explanations given and comments made by the author(s) or editor(s) regarding the approaches taken and means applied in presenting the text and illustrations in the book. The next step was to sort the notes taken on all the 'Preface's on the basis of their similarities. Thus, several 'cluster's of similar Preface-material were formed. Then, each cluster was analysed to come up with a 'theme'. These 'theme's together represented all the main points made in the 'Preface's studied. Figure 1 shows the procedure of analysis of the 'Prefaces'.

\section{Results:}

On qualitative analysis of the 'Preface's of fifteen Histology books, sixteen 'theme's could be identified from the claims made by the author(s)/editor(s). The themes are shown in Table-I. From these sixteen themes, some important points evolved that deserve some elaboration. The details of the results are incorporated into the Discussion section for easier understanding.

Table-I

The main 'theme's emerging from the observations made through the analysis of 'Preface's of fifteen Histology books on the 'approaches taken' and 'means applied' in presenting Cell Biology and Histology.

\begin{tabular}{lr}
\hline Sl. Theme (observation) & No. of \\
no. & books \\
\hline
\end{tabular}

1. Attempts have been made to design the content and amount of Cell Biology and Histology suited 14 to the contemporary reforms in the course curricula of medical institutions

2. The volume of the book has been compressed 9

3. Attempts have been made to incorporate contemporary and new information 11

4. Attention has been focused on better understanding of function based on the structure 12 of cells and tissues

5. Presentation of the information on Cell Biology and Histology has been directed towards their application in medical science

6. A developmental segment has been introduced to discuss how tissues appear the way they do 3

7. A short summary or an 'outline of major headings' has been added/updated 3

8. The format or organisation of the textual or illustrative material has been logically devised 1

9. New text design has been used to ease navigation of the text 1

10. Symbols (icons) or bold types have been used for indicating the key points of the text 3

11. New tables have been included to assist readers in reviewing the learned material and for 3 making comparison

12. New illustrations have been added for greater clarity and conceptual focus 6

13. Some illustrations have been improved either in presentation or by the use of newer techniques 6

14 Some parts of the illustrations are left unlabelled allowing readers to locate and identify them 1

15 Questions have been provided with or without cross-references to the text and answers 4

16 A CD ROM has been provided with the book 1 


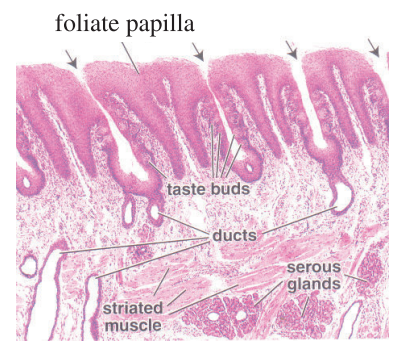

A

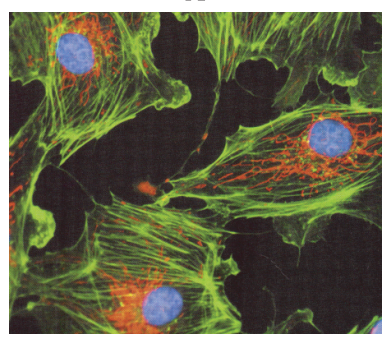

C

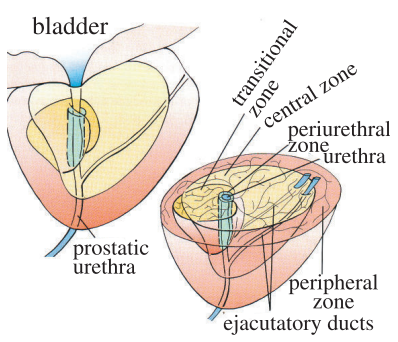

B

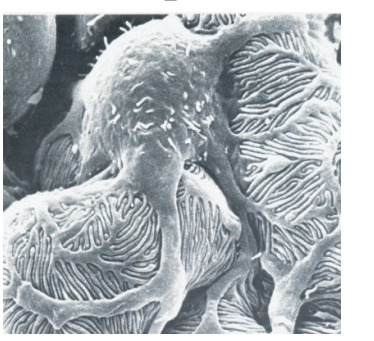

D

Fig.-2: Different forms of illustration: $\boldsymbol{A}$ : 'photomicrograph-routine stain-low power' showing foliate papillae of the tongue; $\boldsymbol{B}$ : 'schematic and threedimensional diagram' showing relative locations, by colour, of the four zones of the prostate gland; $\boldsymbol{C}$ : 'photomicrograph- unconventional technique' showing actin (green), mitochondria (red) and nuclei (blue); D: 'scanning electron micrograph' showing a portion of a glomerulus of human kidney depicting iterdigitations of podocyte cell processes over the surfaces of capillary loops.

(Sources: Ross and Pawlina 2006- A: p. 480; B: p.754; C: p.59; Kelly et al 1984- D: p. 655)

\section{Discussion:}

Incorporation of curricular changes and reduction of text

At least fourteen of the 'Preface's of the books analysed indicate that while writing the books, the author(s)/ editor(s) have tried to incorporate contemporary curricular changes into their designs. ${ }^{2,7,8,17}$ Other good books in the world, it is assumed, have also tried to do the same. Most of the author(s)/editor(s) pointed out that the volume of the Histology books has been compressed keeping in view the reduction of time allocated for Histology in the course curricula for basic medical sciences in recent years. Some reduction has been made in the latest undergraduate medical curriculum of Bangladesh as well. However, some 'Preface's have claimed that despite the deduction of contents, the material has been kept comprehensive, sometimes using some new, and revised illustrations. ${ }^{2}$ Similarly, Cormack $^{2}$ asserts that the coverage for the clinical relevance of the contents has not diminished in the book.

A major shift in the learning method in recent times is the increasing use of computer-aided learning of Histology in increasing number of institutions. It is observed that many foreign medical universities are using this 'virtual microscope' instead of traditional light microscope. Several authors. ${ }^{19,20,21,22}$ claim that virtual microscope may improve student's learning efficiency and also reduce time required for learning.

To overcome the problems of rote memorisation, reduced time allotted to Histology and concise text, some new approaches have been suggested by Drake et al. ${ }^{23}$ for better understanding of Cell Biology and Histology. These include steps like decreased large group lectures, increased small group activities, fewer scheduled activities, increased problem solving approaches and increased use of computer technology in the classroom. Not all of them are always feasible in our country. Yet some steps may be taken as far as practicable. Teaching can address the issues and topics that deal with the understanding and application levels of cognitive domain. This would turn the students' minds away from rote memorisation of mere lists of information.

An expanded knowledge of Cell and Molecular Biology

Much importance has been attached to Cell and Molecular Biology in the good Histology books in recent years. This is revealed in at least nine 'Preface's out of those analysed in the present study. $2,4,8,9,10,11,14,15,17$

Because the study of Histology requires a firm foundation in Cell Biology, Junqueira and Carneiro ${ }^{10}$ have emphasized on the study of Cell Biology for being the "most fundamental approach to the study of structure and function". Incorporation of a significant amount of Cell Biology into textbooks and courses has been an important phenomenon since the later part of the $20^{\text {th }}$ century ${ }^{24}$ Drake et al. ${ }^{23}$ also point out that dramatic advances in Cell and Molecular Biology (in recent times) have increased our understanding of basic physiological processes and the use of this information in the development of better pharmaceuticals for the treatment of diseases. For better understanding of Cell and Molecular Biology, students need to deal with the cells at the electron microscopic and chemical levels. As electron microscopes are not available for the undergraduate medical students of our country, use of electron micrographs for the purpose of learning Cell and Molecular Biology is a viable alternative. Illustrations, especially schematic drawings and animations, are also tremendously useful in understanding cells at the chemical level. 
The teaching and learning of Cell and Molecular Biology should be practically oriented. It may be noted here that the practical part of the undergraduate exams in our country is almost entirely based on light microscopic viewing and light micrographs. But theoretical exposure to Cell Biology remains an integral part of our curriculum. It is essential that students get accustomed to the visual image of what they learn theoretically. Thus, use of highpower microscopy and specialised microscopy, as far as practicable, should be used. In addition, electron micrographs and schematic diagrams related to functionally oriented Cell and Molecular Biology should be added to our assessment toolbox so that the students are also encouraged in using such tools in their learning process.

Importance of structure-function correlation for better understanding of Cell Biology and Histology

The tremendous importance of structure-function correlation in the field of Histology can be realised by understanding the following statement from Wheater et al. ${ }^{25}$

Histology has bored generations of students almost certainly because it has been regarded as the study of structure in isolation from function.

The importance of this correlation in the field of Histology has been highlighted in several of the 'Preface's

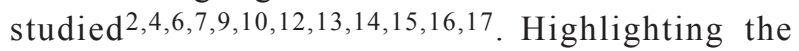
importance of understanding the organisation and function of tissues, Wood and Schechter ${ }^{26}$ point out that in order to achieve it, students require to be able to interpret microscopic images. Leeson et $\mathrm{al}^{13}$ assert that "the correlation between structure and function is essential and perhaps provides the reason that histology is such an intriguing and readily understandable subject". The authors also believe that if the students examine the structure of an organ or tissue, they can deduce much about its function. Conversely, if they know its function, they can forecast more easily much of its microscopic structures. Thus, "Histology stands at the crossroads between gross anatomy and physiology and acts as an integrative element between them". ${ }^{6}$

The importance of incorporation of histophysiology into histology began to be understood in the later part of the $20^{\text {th }}$ century. ${ }^{24}$ Universities in various parts of the world have addressed this important realisation while designing their courses. In the University of Iowa College of Medicine, the departmentally based courses, General Histology for Medical Students and Medical Physiology, have been folded into a single structure/function course entitled 'Human organ systems'. The 'strength' of such courses has been claimed to be the integrated presentation, in one setting, of structure/function concepts and the application of factual material within a clinical context with the aid of clinicians/scientists lecturing in the courses. ${ }^{21}$

Therefore, it may be suggested that the teaching-learning of Cell Biology and Histology should be approached in such a way that functional aspects are understood being related to the corresponding structural aspects, and this approach should be reflected properly in our assessment system as well.

Importance of clinical correlation in Cell Biology and Histology

The study and practice of medicine focuses on what goes wrong in the body and how to restore it to a normal, healthy, functional state. For a physician to succeed in this endeavour, considerable knowledge of both the normal and abnormal structures of the body's cells, tissues and organs is needed. Histology is a branch of medical science that describes the normal appearance and structure of cells, tissues and organs at the microscopic level. Studying Histology with a curious eye and mind will improve the diagnostic and clinical abilities of medical students accordingly. In this regard, Fawcett ${ }^{4}$ believes that a firm foundation in Histology continues to be essential for recognising and interpreting their changes in disease. Most (ten) of the 'Preface's analysed in the present study have specifically highlighted clinical correlation of Cell Biology and/or Histology 2,4,6,7,10,12,13,15,16,17, thus emphasizing the application of the subjects in medical science.

Clinically oriented Histology teaching is not a new concept in most medical schools of the medically advanced countries of the world. Clinical orientation has been a phenomenon of the undergraduate courses since the later part of the $20^{\text {th }}$ century. ${ }^{24}$ This is also reflected in the Histology textbooks commonly used by the undergraduate medical students of Bangladesh. Integrated teaching of Histology, Physiology and Pathology are not uncommon in world's renowned universities. In the University of New South Wales, Australia, learning of histology has been successfully integrated with histopathology. ${ }^{26}$

It is well known that adults learn topics that they feel relevant. If Cell Biology and Histology can be clinically correlated in teaching and assessment, students would hopefully take more interest in the subjects. This is because students then would realise where these subjects stand 
in the context of their future clinical careers as has been experienced by the students of the University of New South Wales. ${ }^{27}$ It is difficult to ensure asking questions related to clinical Histology in the oral exams of our courses. But some amount of clinical Histology and clinical aspects of Cell Biology may be incorporated in the written questions. Objective Structured Practical Exams (OSPE) may also be designed to incorporate clinical aspects of Histology.

Incorporation of questions in some Histology books Several of the 'Preface's analysed in the present study mention the use of questions in the book for self assessment. ${ }^{7,8,9,12}$ Observations made in the available books suggest that many of these questions are at the understanding level. Self-assessment using such questions increases students' understanding of the subjects and makes reading of the book interesting. Selfassessment helps them in the process of becoming selfdirected learners as well. Like many universities, the University at Buffalo in the US uses multiple choice questions constructed from images. ${ }^{28}$ Use of printed images in constructing questions may be an effective but economic way of assessment.

It is generally observed that the undergraduate medical students in Bangladesh rarely practice answering the questions provided in their textbooks. Teachers are often so overburdened with the administrative aspects of running the course (due to the poverty of workforce) that they very often complain of not getting enough time to construct good innovative new questions. Questions selected from the Histology books or online sources may be a good tool in keeping Bangladeshi students in practice of being assessed and thus being benefited by developing better understanding of Cell Biology and Histology.

The importance of the use of illustration

An illustration is a picture that depicts or enhances a piece of text. Illustrations are used for the decoration or explanation of a text, or to reinforce concepts and thoughts delivered in written composition. ${ }^{29}$ The analyses of 'Preface's revealed that there is a tendency in the Histology books to increase the number of illustrations with each edition. Special mention about this has been made in Cormak, ${ }^{2}$ Gartner and Hiatt ${ }^{6}$ and Leeson et al. ${ }^{14}$ The new illustrations include clinical pictures, photomicrographs (e.g., high resolution digital photomicrographs, fluorescent microscographs), scanning and transmission electrons micrographs, micrographs of freeze-etch material and also new diagrams (schematic diagrams).
These illustrations have been claimed to summarise the materials of the text ${ }^{17}$ and make the presentation of Cell Biology and Histology comprehensive. ${ }^{7}$ Several authors/ editors mention in the 'Preface's of newer editions that most of the figures in their books have been redrawn or improved either in presentation or by the use of newer technique in the newer editions. Some of them. ${ }^{10,15,17}$ state that all their existing illustrations have been revised, updated or improved. Two 'Preface's ${ }^{10,17}$ draw the reader's attention by saying that the clarity of their illustrations has been improved by changing them into the full colour format. Mentions are also there regarding improved presentation of illustration by virtue of the development of new technique or equipments such as autoradiography, freeze fracture method, electron microscopy, high resolution digital photomicrography. Telser et al. ${ }^{16}$ has left some parts of the illustration unlabelled while labelling the other parts. Thus, the readers can perform self-driven exercises.

It is understandable that several 'form's of illustration are required for developing a proper understanding of the structure and function of cells, tissues and organs. Some examples of illustrations of different forms are shown in Figure 2. There are some structural components that are not visualised clearly without using special fixation and staining methods or other special techniques. Many of these techniques and methods are not yet easily available in our country. But it is important for the students to have clear ideas of these structures. Such type of Illustration as shown in Figure 2C can serve as alternatives to histological and cytological specimens prepared using special fixatives and stains or other special techniques. 'Schematic and three-dimensional diagram's is a form of illustration that may not be able to show the morphological details, but can express mechanisms, phenomena, functional aspects and pathogenesis or even can express concepts or ideas that are more abstract than visible. Flow charts are also included in recent books to show sequences of events in cellular differentiation, activity etc. In Histology classes, the Bangladeshi students are usually habituated with twodimensional view of a structure in section under a low power light microscope (as shown in Figure 2A). They often forget that the structures they are looking at are actually three-dimensional ones. For teaching Cell Biology, probably more than for Histology, schematic and threedimensional diagrams (as shown in Figure 2B) is the tool of choice along with electron micrographs (as shown in Figure 2D). As electron microscopes are not yet widely available in our country, institutions can resort to using electron micrographs. This is especially true for Cell Biology. 
It is needless to say that among the different disciplines of basic sciences, the importance of illustrations in Cell Biology and Histology has special implication because Cell Biology and Histology is an image-intensive discipline. Illustrations aid in the recognition of histological structures in the field of microscope (Miller 1891, cited in Cotter $^{28}$ ). Ross and Pawlina ${ }^{15}$ believe that illustrations act as a visual memory tool to facilitate learning. The present researcher has noted that the Histology textbook most commonly recommended for the undergraduates of Bangladesh, Junqueira and Carneiro has used more than $60 \%$ of its printed area for illustrations.

As revealed from informal communications with the teachers in Anatomy, the majority of students of most medical colleges of Bangladesh are interested in 'identifying' histological slides not through the lens of the microscope but form outside. In 'describing' the histological structures of different organs, they tend to prepare a list of characters or components supposed to be present in a section of the organ one after another, not recognising their logical interrelationship, structural orientation or their recognisability at a particular level of magnification. Moreover, in Bangladesh, there is no use of illustrations in the oral part of the First Profesional MBBS Histology exams as it is not specified in the curriculum. Although use of illustrations has recently been introduced in the practical part of Histology exams, but the proportion does not seem to be sufficient and the directives are not well structured.

It as well understood that Cell Biology and Histology are structure-oriented subjects where appearances of cellular and tissue structure speak for their functions. Therefore, better use of illustrations in the teaching and learning process as well as in assessment would add to better understanding of those subjects. Introduction of the use of illustrations in the oral part of the undergraduate exams and increase in their use in the practical exams have every likelihood of improving the quality of exams because by this the exams can thus be raised to a more understanding level. At the same time, an enhanced use of illustration would motivate students to make better use of illustration in their self-learning of Cell Biology and Histology from books and other sources. As there is paucity of good slides in many medical colleges of the country and because the use of high magnification is a rarity in practice, use of printed illustrations in classes as well as in exams becomes a necessity to be outlined and ensured by the relevant authorities.

\section{Conclusion:}

The present study was undertaken to contribute to the improvement of teaching-learning and assessment in Cell Biology and Histology in the undergraduate medical courses of Bangladesh. It may have been able to make some important points and create an evidence-based foundation upon which positive steps may be taken in future towards fulfilling the objectives set in the undergraduate curriculum.

By incorporating the findings of the present study with the present-day ideas and trends in Cell Biology and Histology teaching-learning and assessment in the renowned universities of the world, as evident from the available literature, suggestions can be formulated on improving the methods of teaching and assessment in Cell Biology and Histology in Bangladesh.

\section{Acknowledgement:}

The study was partly supported by a grant from the Ministry of Science and Technology of the Govt. of the People's Republic of Bangladesh.

\section{References:}

1. Curriculum of Anatomy course for undergraduate medical students of Bangladesh- Compiled and Edited by Center for Medical Education (CME). Dhaka: Bangladesh Medical and Dental council; 2002.

2. Cormack DH, ed. Ham's Histology. $9^{\text {th }}$ ed. Philadelphia: J.B. Lippincott Company; 1987.

3. Module on $1^{\text {st }}$ professional MBBS examination system to be held on January 2008 based on new curriculum. Dhaka: Core group, Faculty of Undergraduate Medicine, University of Dhaka.

4. Fawcett DW, ed. Bloom and Fawcett- a text- book of histology. $12^{\text {th }}$ ed. New York: Chapman and Hall; 1994.

5. Grag K, Bahl I, Kaul M. A text book of Histology. $2^{\text {nd }}$ ed. Delhi: CBS Publishers and Distributors; 1987.

6. Gartner LP, Hiatt JL. Color textbook of histology. 2nd ed. Baltimore: Saunders; 2001.

7. Gartner LP, Hiatt JL, Strum JM. Cell biology and histology. 5th ed. Philadelphia: Lippincott Williams and Wilkins; 2007.

8. Henrikson RC, Kaye GI, Mazurkiewicz JE. Histology. Baltimore: Williams and Wilkins; 1997.

9. Johnson KE. Histology and cell biology. $2^{\text {nd }}$ ed. Baltimore: Williams and Wilkins; 1991.

10. Junqueira LJ, Carneiro J. Basic histology- text and atlas. $11^{\text {th }}$ ed. New York: McGraw-Hill; 2006.

11. Kelly DE, Wood RL. Enders AC, editors. Bailey's textbook of microscopic anatomy. $18^{\text {th }}$ ed. Baltimore: Williams and Wilkins; 1984. 
12. Krause WJ, Cutts JH. Essentials of histology- text / atlas / review. Boston: Little, Brown and Company; 1994.

13. Leeson TS, Leeson CR, Paparo AA. Text/atlas of histology. Philadelphia: W.B. Saunders Company; 1988.

14. Leeson TS, Leeson CR, Paparo AA. Textbook of histology. 5th ed. Philadelphia: W.B. Saunders Company; 1985.

15. Ross MH, Pawlina W. Histology- a text and atlas with correlated cell and molecular biology. $5^{\text {th }}$ ed. Baltimore: Lippincott Williams and Wilkins; 2006.

16. Telser AG, Young JK, Baldwin KM. Elsevier's integrated histology. Philadelphia: Mosby Elsevier; 2007.

17. Young B, Heath JW, editors. Wheater's functional histologya text and colour atlas. $4^{\text {th }}$ ed. Edinburgh: Churchill Livingstone; 2000 .

18. Oxford learner's pocket dictionary. $4^{\text {th }}$ ed. Oxford: Oxford University press; 2011. Preface; p. 346.

19. Bloodgood RA, Ogilvie RW. Trends in histology laboratory teaching in United States medical schools. The Anatomical Record (Part B: New Anatomist), 2006; 289B: 169-175.

20. Harris T, Leaven T, Heidger P, Kreiter C, Duncan J, Dick F. Comparison of a virtual microscope laboratory to a regular microscope laboratory for teaching histology. The Anatomical Record ((New Anatomist), 2001; 265: 10-14.

21. Heidger JR, PM, Dee F, Consoer D, Leaven T, Duncan J, Kreiter C. Integrated approach to teaching and testing in histology with real and virtual imaging. The Anatomical Record (New Anatomist). 269: 107-112.

22. Krippendorf BB , Lough J. Complete and rapid switch from light microscopy to virtual microscopy for teaching medical histology. The Anatomical Records (Part B: New Anatomist). 2005; 285: 19-25.

23. Drake RL, Lowrie DJ, Prewitt CM. Survey of gross anatomy, microscopic anatomy, neuroscience, and embryology courses in medical school curricula in the United States. The Anatomical Record (New Anatomist), 2002; 269: 118-112.

24. Blake CA, Lavaie HA, Millette CF. Teaching medical histology at the University of South Carolina school of Medicine transition to virtual slides and virtual microscopes. The Anatomical Record (Part B; New Anatomist) [Internet]. 2003, 275B(1); 196-206. Available from: Onlinelibrary.wiley.com/ doi/10.1002/ar.b.10037/ful

25. Wheater PR, Burkitt HG, Daniels V G, Wheater's functional histology- a text and colour atlas. $1^{\text {st }}$ ed. Edinburgh: Churchill Livingstone; 1979.

26. Wood RI, Schechter, JE. Histology- an interactive virtual microscope [Internet]. 2002. Available from:http:// icb.oxfordjournals.org/content/43/2/360.full

27. Kumar RK, Fruman B, Vclan GM, D, Permontier PJ. Integrating histology and histopathology teaching in practical classes using virtual slide. The Anatomical Record (Part B; New Anatomist) [Internet]. 2006,289B: 128-133. Available from: virtualslides, unsw. edu. au/docs/integrated_ virtual_microscopy.

28. Cotter JR. Laboratory instruction in histology at the University at Buffalo: recent replacement of microscope exercises with computer applications. The Anatomical Record (New Anatomist), 2001; 256: 212-221.

29. Top: Arts: Illustration [Internet] [Cited 2008 Nov13]. Available from: http://opensite.org/arts/illustration. 